\title{
INNOVATIVE LEARNING MODEL WITH INCLUSIVE- COLLABORATIVE APPROACH FOR STUDENTS WITH SPECIAL NEEDS
}

\author{
Fermanto Lianto $^{1}$, Nafiah Solikhah ${ }^{2 *}$, Andi S. Kurnia ${ }^{3}$, Franky Liauw ${ }^{4}$, Margaretha \\ Syandi $^{5}$, Caroline S. Kurniawan ${ }^{6}$
}
${ }^{1}$ Jurusan Arsitektur dan Perencanaan, Universitas Tarumanagara Jakarta Email: fermantol@ft.untar.ac.id
${ }^{2}$ Jurusan Arsitektur dan Perencanaan, Universitas Tarumanagara Jakarta Email:nafiahs@ft.untar.ac.id
${ }^{3}$ Jurusan Arsitektur dan Perencanaan, Universitas Tarumanagara Jakarta Email:andik@ft.untar.ac.id
${ }^{4}$ Jurusan Arsitektur dan Perencanaan, Universitas Tarumanagara Jakarta Email: frankyl@ft.untar.ac.id
${ }^{5}$ Jurusan Arsitektur dan Perencanaan, Universitas Tarumanagara Jakarta Email: margarethas@ft.untar.ac.id
${ }^{6}$ Jurusan Arsitektur dan Perencanaan, Universitas Tarumanagara Jakarta Email: carolinesunjayak@gmail.com

\begin{abstract}
In order to face the era of technological disruption and the industrial revolution 4.0, it is necessary to improve the curriculum and educational methods for the Bachelor of Architecture that is friendly for disabilities. Therefore, it is necessary to innovate, research, and apply online and digital technology, architectural computing systems that can be utilized optimally in XYZ University's architectural education model. Architectural education must be sensitive and do self-introspection so that it can detect its position during the rapid development of science and technology. Specialized classroom design includes seating position, layout, optimized space, and usage of special computer applications to help students with disabilities in the study and learning process. The methodology approach used Descriptive, experimental, and quantitative methods based on an interdisciplinary approach centralized on psychological methods and designing facilities that support the learning process. The research resulted in designating a position in the classroom that is ideal for a student with disabilities. This position helps them to participate in the classroom efficiently. Equipment such as speakers and an LED TV is placed to help people with disabilities. Transcription software is used to transcribe lecturers in real-time. This research was conducted with the use of compatible software to get optimal results. Several methods and tools are used to support this research to obtain optimal results for the learning process, especially for people who are deaf or have low vision. Audio and visual aspects are prioritized without neglecting other supporting aspects.
\end{abstract}

Keywords: Disabilities, innovative learning, inclusive-collaborative, assistive technology

\begin{abstract}
ABSTRAK
Dalam rangka menghadapi era disrupsi teknologi dan revolusi industri 4.0, perlu dilakukan penyempurnaan kurikulum dan metode pendidikan Sarjana Arsitektur yang ramah bagi disabilitas. Oleh karena itu perlu dilakukan inovasi, riset, dan menerapkan teknologi online dan digital, sistem komputasi arsitektural yang dapat dimanfaatkan secara optimal dalam model pendidikan arsitektur Universitas XYZ. Pendidikan arsitektur harus peka dan melakukan introspeksi diri sehingga mampu mendeteksi posisinya di tengah perkembangan ilmu pengetahuan dan teknologi yang begitu cepat. Desain ruang kelas khusus mencakup posisi tempat duduk, tata letak, ruang yang dioptimalkan, dan penggunaan aplikasi komputer khusus untuk membantu siswa penyandang disabilitas dalam proses belajar dan belajar. Pendekatan metodologi yang digunakan adalah metode Deskriptif, eksperimental, dan kuantitatif berdasarkan pendekatan interdisipliner, terpusat pada metode psikologis dan merancang fasilitas yang mendukung proses pembelajaran. Penelitian ini menghasilkan penunjukan posisi di kelas yang ideal bagi siswa penyandang disabilitas. Posisi ini membantu mereka untuk berpartisipasi di dalam kelas secara efisien. Perlengkapan seperti speaker dan TV LED ditempatkan untuk membantu para penyandang disabilitas. Software transkripsi digunakan untuk mentranskripsi dosen secara real-time. Penelitian ini dilakukan dengan menggunakan software yang kompatibel untuk mendapatkan hasil yang optimal. Beberapa metode dan alat digunakan untuk mendukung penelitian ini agar mendapatkan hasil
\end{abstract}


yang optimal untuk proses pembelajaran, terutama bagi penyandang tunarungu atau low vision. Aspek audio dan visual diprioritaskan tanpa mengabaikan aspek pendukung lainnya.

Kata Kunci: Disabilitas, pembelajaran inovatif inklusif-kolaboratif, teknologi bantu

\section{INTRODUCTION}

"Mahasiswa Berkebutuhan Khusus/MBK (Students with Special Needs)" or "Penyandang Berkebutuhan Khusus (person with disabilities)" are terms used to describe handicapped students. These students face difficulties when doing certain activities. The specialized tool, environment modification, or alternate technique are used to help these students participate efficiently in the learning and studying process. In the future, these students will be able to participate and be productive citizens in society (Junaidi, 2020). The aim of specialized education at study institutions is to improve the learning and to study the process of MBK (Dikti, 2017); another aim is to give these students a chance to obtain the equal quality of education as students without handicaps (Ishartiwi, 2010; Praktiningrum, 2010; Smith, 2006).

Inclusive learning is a system that lets all students, regardless of their condition or disabilities to join the same learning environment as general students. Sometimes students with disabilities have a unique talent or potential to be intelligent (Diknas, 2009). Innovative learning Models and Assistive technology are used to do inclusive learning. The Specialized design of the classroom is one of the Innovative Learning models. These classrooms let the student with disabilities participate actively in the learning and study process. Research, Innovation, Implementation of Technology, and Computing systems are used to support the Innovative Learning Model. Specialized classroom design includes seating position, layout, optimized space, and usage of special computer applications to help students with disabilities in the study and learning process. This research focused on students with hearing disabilities, vision disabilities, and disabled students with the wheelchair.

Based on "Undang-Undang No. 8 Tahun 2016 Tentang Penyandang Disabilitas", Persons with Disabilities are every person who experiences physical, intellectual, mental, and sensory limitations for an extended period who in interacting with the environment may experience obstacles and difficulties to participate fully and effectively with other citizens. However, many people with special needs have high academic potential and motivation to continue their education to higher education.

All disabilities are the inability to do something, but not all of these are disabilities (Hallahan et al., 2018). The World Health Organization (WHO) defines disability, namely the limitations or inability of a person to perform an activity, usually used at the individual level (Desiningrum, 2016).

Individuals with Disabilities Education Act Amendments (IDEA) 1997, which was reviewed in 2004, generally classifies disabilities into three classes, namely: (a) physical disabilities; (b) emotional and behavioral disabilities; (c) intellectual disability, which includes physical disabilities, namely: tunarungu (deaf), tunanetra (blind), and tunadaksa (physical disabilities). Furthermore, those included in emotional and behavioral disabilities are tunalaras (laras disabilities), communication disorders, and hyperactivity. The last one is included in intellectual disabilities tunagrahita (grahita disability), slow learner, unique learning difficulties, gifted children, autism, and indigo (Desiningrum, 2016). 
Architecture is a complex and dynamic field of science. In its development in the early twentieth century, the relationship between architecture and other fields of science became increasingly loud in architectural discussions. One that is consistently echoed in the architectural context related to the work of the mind/brain, initiated by Juhani Pallasmaa and Harry Francis Mallgrave. During their development, Pallasmaa and Mallgrave sharpened the previous architectural context on the relationship between architecture and empathy (Pallasmaa et al., 2015), which seeks to sharpen the sensitivity in seeing, hearing, smelling, tasting, and feeling what those with physical limitations feel are generally categorized as physical disabilities. Empathy emphasizes being with other people more than relationships that place other people as manipulative objects (Bullmer, 1975). Architecture and empathy are closely related because studying human empathy as a user of architecture can meet human physical and psychological needs. The relationship between architecture and empathy will produce an emphatic design if you pay attention to the user's feelings towards the design results. This emphatic design will also have a significant impact on people with disabilities. This design is based on observations that aim to identify the needs of the design user, which even in some cases, the design user does not know their own needs (Patria et al., 2018).

Based on the experience that has been had by the Bachelor of Architecture Study Program, XYZ University has graduated more than 2 (two) students with special needs with details of $2 \mathrm{MBK}$ for the Deaf in the last 5 years/4 MBK for the Deaf in the last 10 years, 2 MBK for tunadaksa (physical disabilities) in 5 years. There are challenges and obstacles in the MBK learning process. For MBK with physical disabilities, the problem can be relatively easily solved by providing supporting facilities (ramps, lifts, and activity rooms with dimensions that allow for wheelchairs), however, for communication, there are no problems because people with disabilities can still attend lectures. The reverse condition occurs for the Deaf MBK who can still carry out activities like normal students. However, the Deaf MBK has limitations in understanding how to capture material in audio because of hearing limitations. This research focuses on arranging classrooms to meet the requirements and quality standards for MBK and creating an emphatic design.

\section{RESEARCH METHOD}

The method used is descriptive and experimental qualitative methods with an interdisciplinary approach, especially related to psychological studies and the design of facilities that support learning assisted by using specific software to get optimal results. One of the rooms that will be taken as a sample is the Banjar 7-1 room because it has a capacity of up to 160 students and is equipped with lecture facilities for the Architectural Design Studio. Activities planned to support the objectives of the program for drafting the innovation model development method consist of several stages as follows; 1) survey the classrooms that will be used as a case study (Banjar 7-1), record the size and area of the room, capacity, layout of tables and chairs, position of lights, speakers, and direction of sunlight; 2) conducting a focus group discussion (FGD) with the resource persons and MBK who have become alumni, to get input on the difficulties faced while studying; 3 ) checking the classroom (building performance) by using specific software, to get a suitable layout (especially for the deaf \& low vision); 4) re-layout the classrooms (simulation of classrooms that respond to the needs of MBK), and add the necessary equipment as the output of the software; 5) testing/simulation and concluding a prototype design drawing.

In general, the innovation model that will be produced is an innovative learning model in the form of media that can support learning for MBK. The design of the Innovation Model that will be produced to help the learning process for MBK which is equipped with technology and inner space prototypes to help the MBK learning process in improving learning space facilities by designing optimal seating positions, layouts and atmosphere of space, and equipped with applications - 
applications that support classrooms for MBK. In this research, the focus is on people with hearing disabilities and wheelchair users.

The specifications and characteristics of the MBK will be used as parameters to calculate in full what needs to be considered. It will improve the quality of spatial facilities, including:

a) An acoustic room system that takes reverberation time into account for the deaf.

b) Lighting (for low vision/double vision).

c) Simulation of building performance will make the effectiveness of classrooms and support the limitations of MBK, especially the deaf.

d) Adding additional application features for classrooms according to the needs of the MBK, especially the deaf and low vision.

To support the implementation of innovative learning models for MBK in the Architecture Study Program, Department of Architecture and Planning, Faculty of Engineering, XYZ University, it is determined that the Design of the Innovation Model is used to support innovative learning models, including improving learning facilities with applications that assist students with special needs. Specifically, in the learning process, significantly to improve the quality of spatial facilities in learning for MBK, namely:

a) Building Performance Simulation's measurement method produces classrooms with characteristics and comfort with MBK hypersensitivity, especially for the deaf.

b) The simulation method uses DIAlux for lighting suitable for MBK by calculating the energy consumption of a lighting design project.

c) Use the Sefaira Plugin on SketchUp to calculate classroom optimization to suit the needs of MBK characteristics by discussing detailed material formulations and various suitable classroom design schemes.

d) Precisely formulating classrooms for integrated MBK in the form of standardization prototypes of classroom formulations by calculating material specifications, space organization, lighting, and air conditioning to suit the sensitivity level and needs of the MBK.

\section{RESULT AND DISCUSSION}

Deaf MBK has limitations in understanding and capturing audio material due to hearing limitations. MBK, which has limited visibility (low vision), is also less comfortable in attending lectures. One of the lecture rooms that will be taken as a sample is the "Banjar" room 7-1 (Figure 1) because it has a capacity of up to 47 students and is equipped with lecture infrastructure for the Architectural Design Studio. 


\section{Figure 1}

The Arrangement and The Atmosphere of The "Banjar 7-1" Classroom
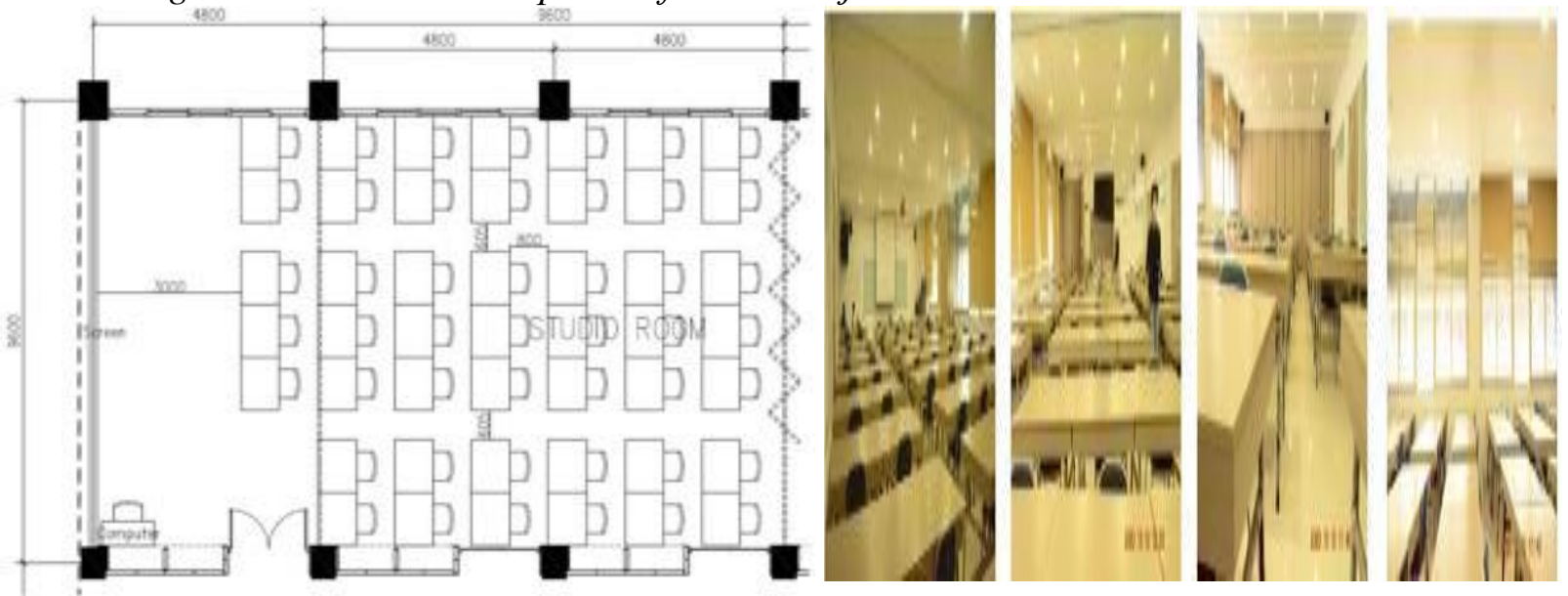

As for determining the MBK that will be followed up, those who have the competence to attend lectures at the Bachelor of Architecture Study Program, namely people with Low Vision, Disability, and Deaf.

\section{Table 1}

MBK Criteria nd Aspects of Architectural Elements in Architectural Studio Classrooms

\begin{tabular}{|c|c|c|}
\hline No. & MBK criteria & $\begin{array}{c}\text { Aspects of Architectural Elements in the Architectural Design Studio } \\
\text { Classroom }\end{array}$ \\
\hline \multirow[t]{4}{*}{1} & \multirow[t]{4}{*}{ Low Vision } & Visibility \\
\hline & & Lighting \\
\hline & & Classroom Materials \\
\hline & & Configuration \\
\hline \multirow[t]{2}{*}{2} & \multirow[t]{2}{*}{ Disability } & Accessibility \\
\hline & & $\begin{array}{l}\text { Provision of friendly furniture with physical limitations (the position of } \\
\text { the studio drawing table) }\end{array}$ \\
\hline \multirow[t]{4}{*}{3} & \multirow[t]{4}{*}{ Deaf } & Acoustic \\
\hline & & Visibility \\
\hline & & Time of Buzz \\
\hline & & Classroom Desk Orientation \\
\hline
\end{tabular}

In response to the need's analysis, a blueprint for architectural element formulations was produced for Classrooms in "Banjar 7-1" based on an integrated approach and MBK-friendly as an architectural design studio classroom (Table 2): (a) innovative learning model/assistive technology; based on the description above, the design of the innovative learning model/assistive technology is produced in the form of an innovative learning model with an inclusive-collaborative approach for students with special needs in the architecture study program, department of architecture and planning, faculty of engineering, XYZ university, especially people with deaf disabilities; (b) model specifications, the resulting model is a blueprint of classroom design to support architectural design studio lectures in "Banjar 7-1". 
Innovative Learning Model With Inclusive-Collaborative

Lianto et al. Approach for Students With Special Needs

\section{Table 2}

The Classroom Formulation Program Simulation Results

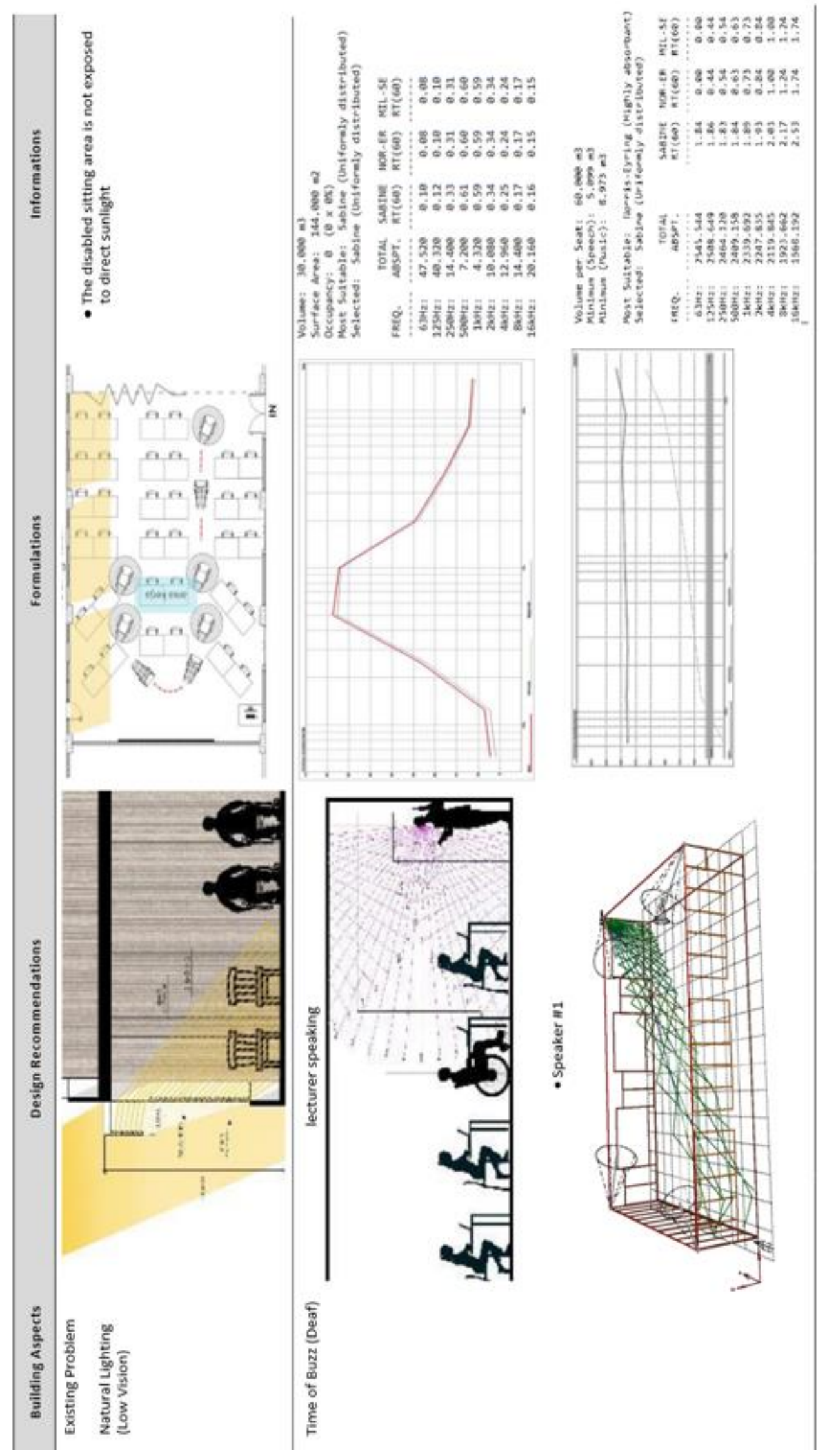



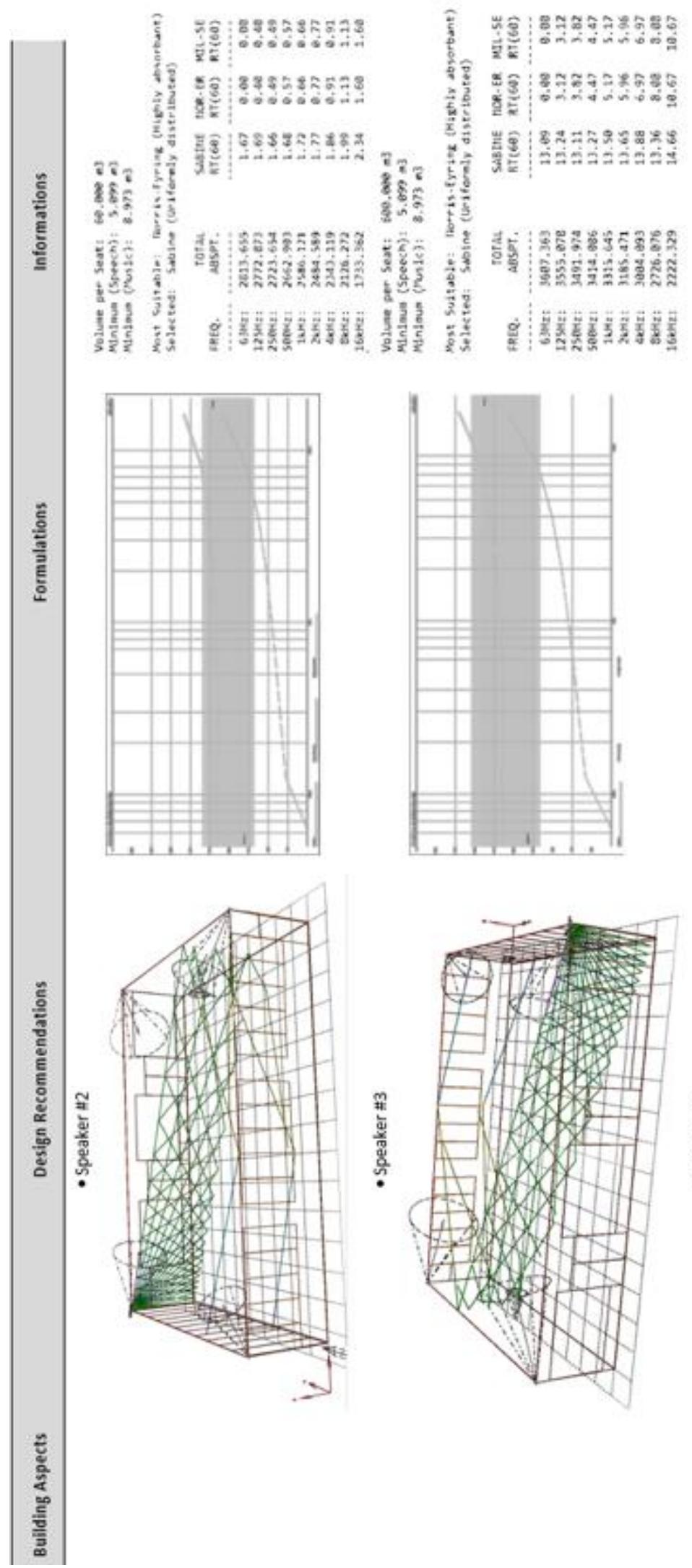

จ จ 8

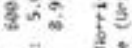

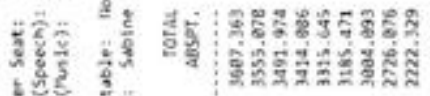

$8+82=$

$8)^{2}$

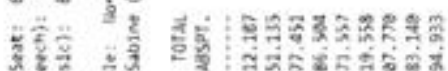

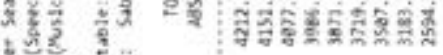

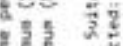
tक
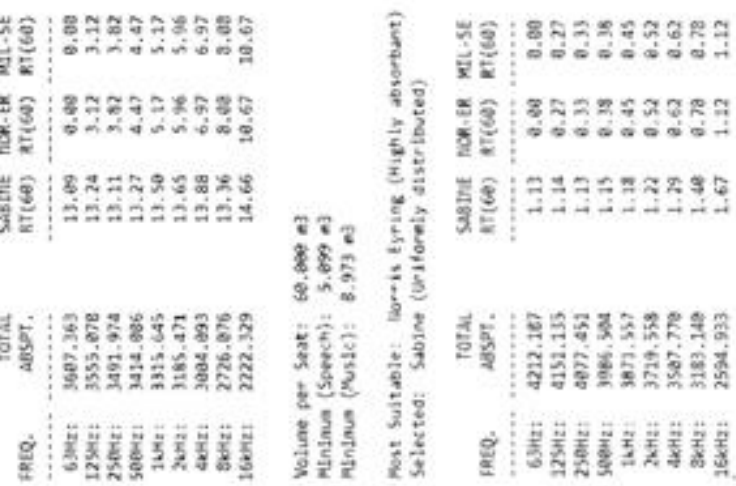

un!
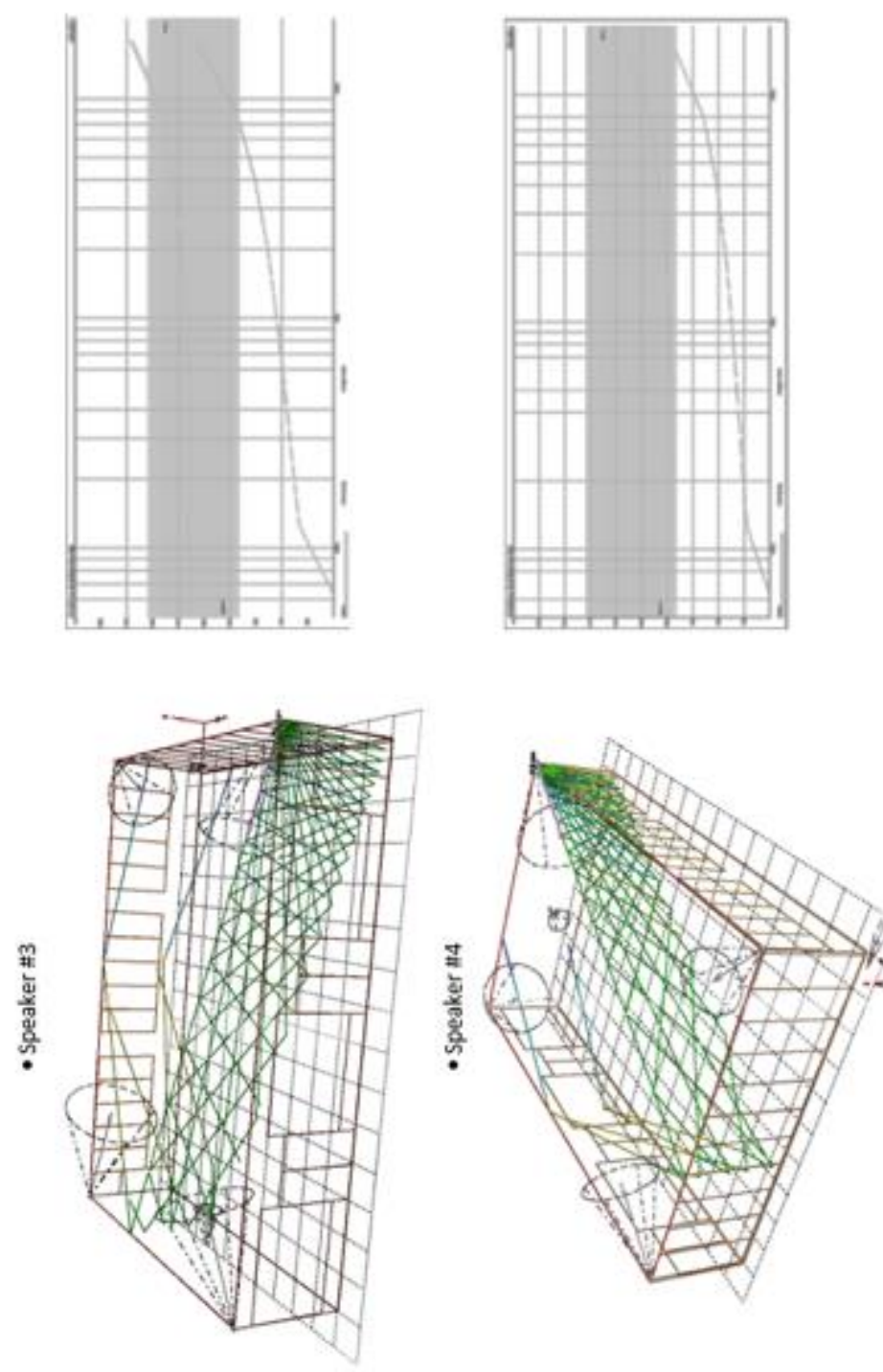


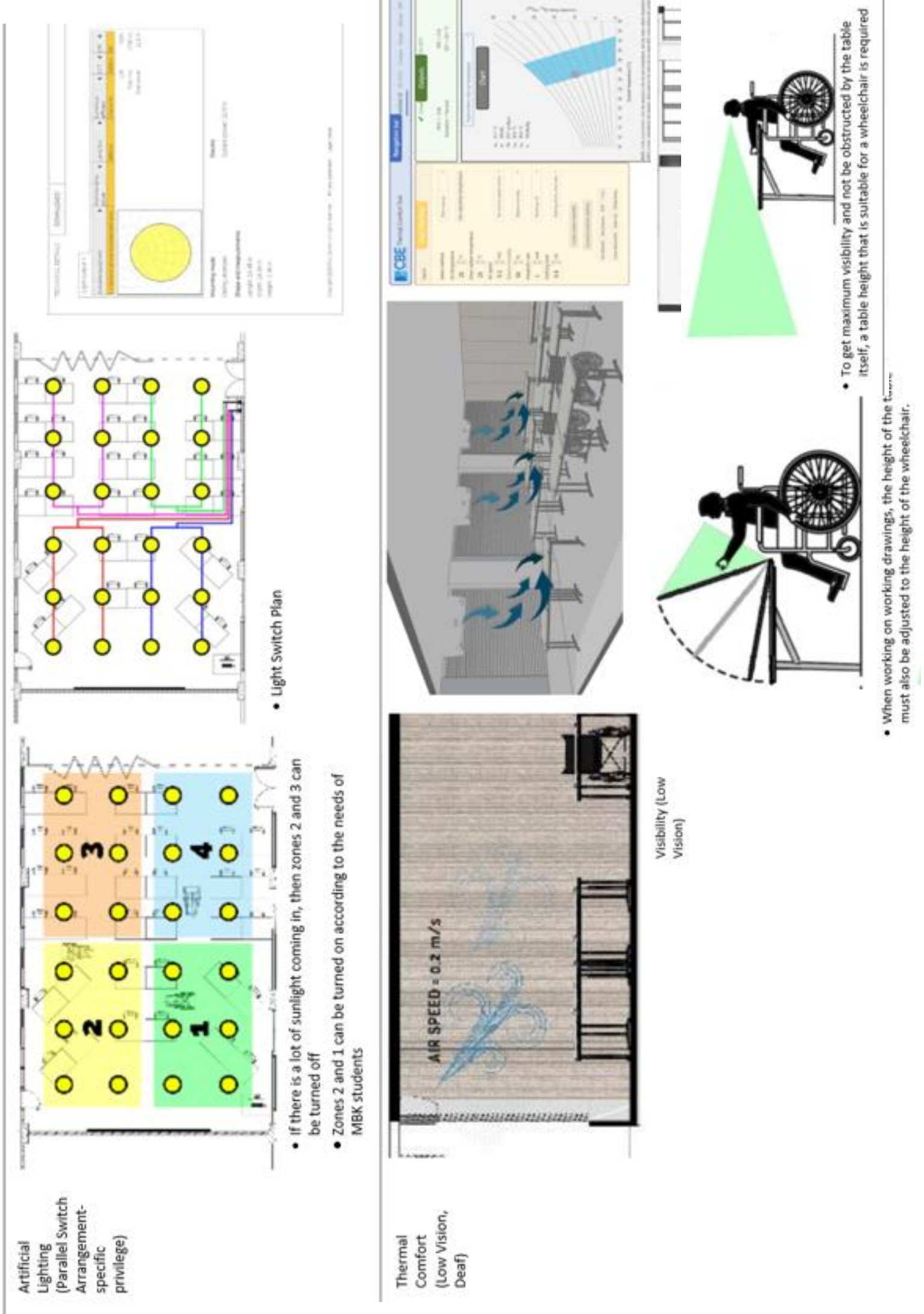


To support the learning process for the Deaf MBK, an LED TV is added in front of the classroom, which is connected to the Transcribe application on the Mobile Handphone (HP) through the screen mirroring and Chromecast applications, so that the Deaf MBK can follow the lecturer's conversation by reading the text that appears on the LED TV screen. The analysis results using the assistance of various tools and technology adapted to the "Banjar 7-1" architectural design studio room as a case study resulted in a re-layout of furniture and the ideal position for persons with disabilities in the classroom, as shown in Figure 2.

\section{Figure 2}

The Classroom Formulation Program Simulation Results

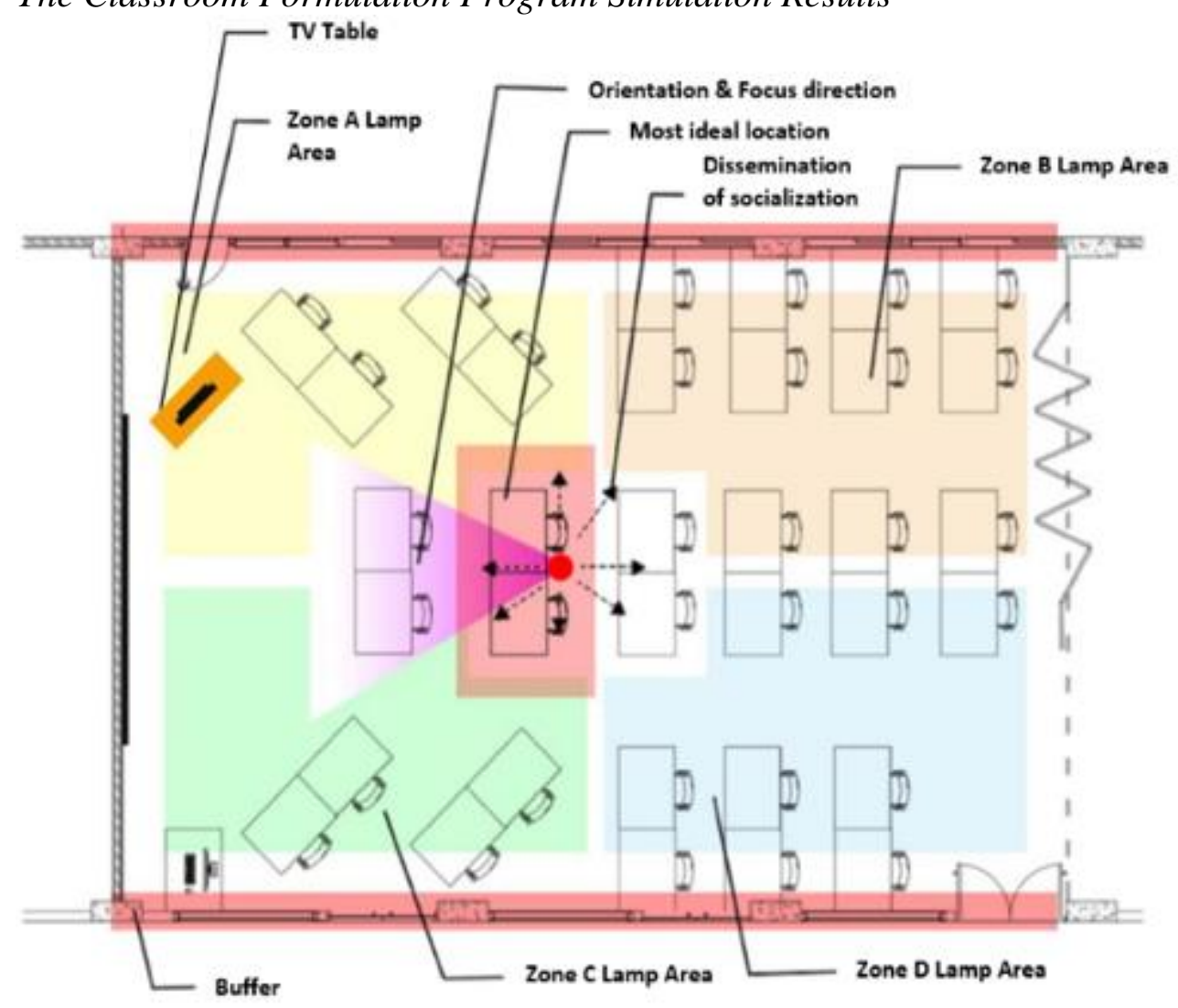

After going through the theoretical analysis process, direct trials were carried out in the classroom. Classrooms are arranged according to theoretical studies. Two rows of tables and chairs at the front are arranged so that persons with disabilities in wheelchairs can Manoeuvre freely in and out of the classroom (Figure 3). In addition to the screen, a LED TV monitor is added that is connected to the lecturer's cell phone so that when the lecturer speaks, the text immediately appears in accordance with what the lecturer said (Figure 4). Thus, lectures in the classroom can be followed by persons with disabilities in wheelchairs or hearing impairments, and students with wheelchair disabilities mingle with other students (Figure 5). 


\section{Figure 3}

Corridor Paths That Allow Persons With Disabilities To Use Wheelchairs

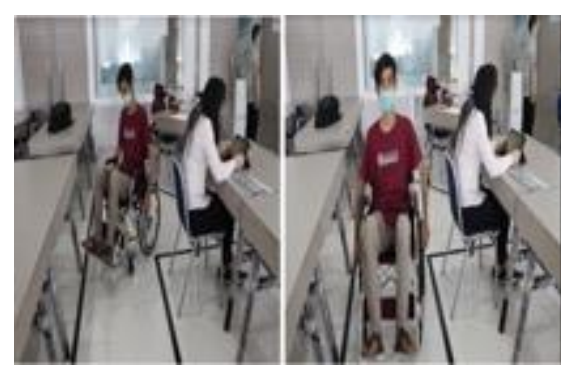

Figure 4

For Lecturers With Disabilities Who Use Wheelchairs, On The Left Is A Led Tv Screen That Text The Lecturer's Speech

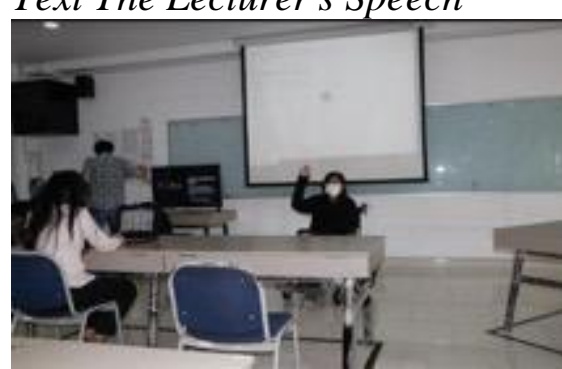

Figure 5

Students With Disabilities Who Use Wheelchairs Mingle With Other Students

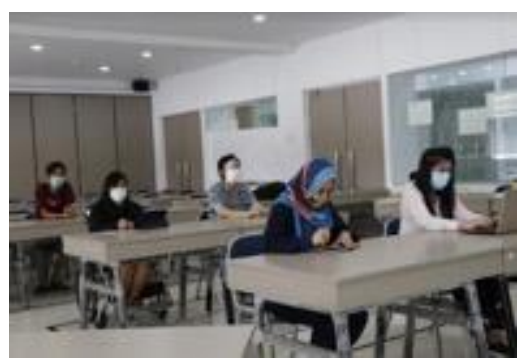

In addition, this lecture simulation is connected online to the participating students in their respective homes, using the Microsoft teams. What the lecturer said in the classroom also appeared as text on each participant's computer screen at home. The trial was relatively effective; it can still be improved by getting used to the speed and intonation of the lecturers' speech so that the text that appears on the screen is what is being said (Figure 6).

\section{Figure 6}

Online and Offline Lecture Simulation Trial Process

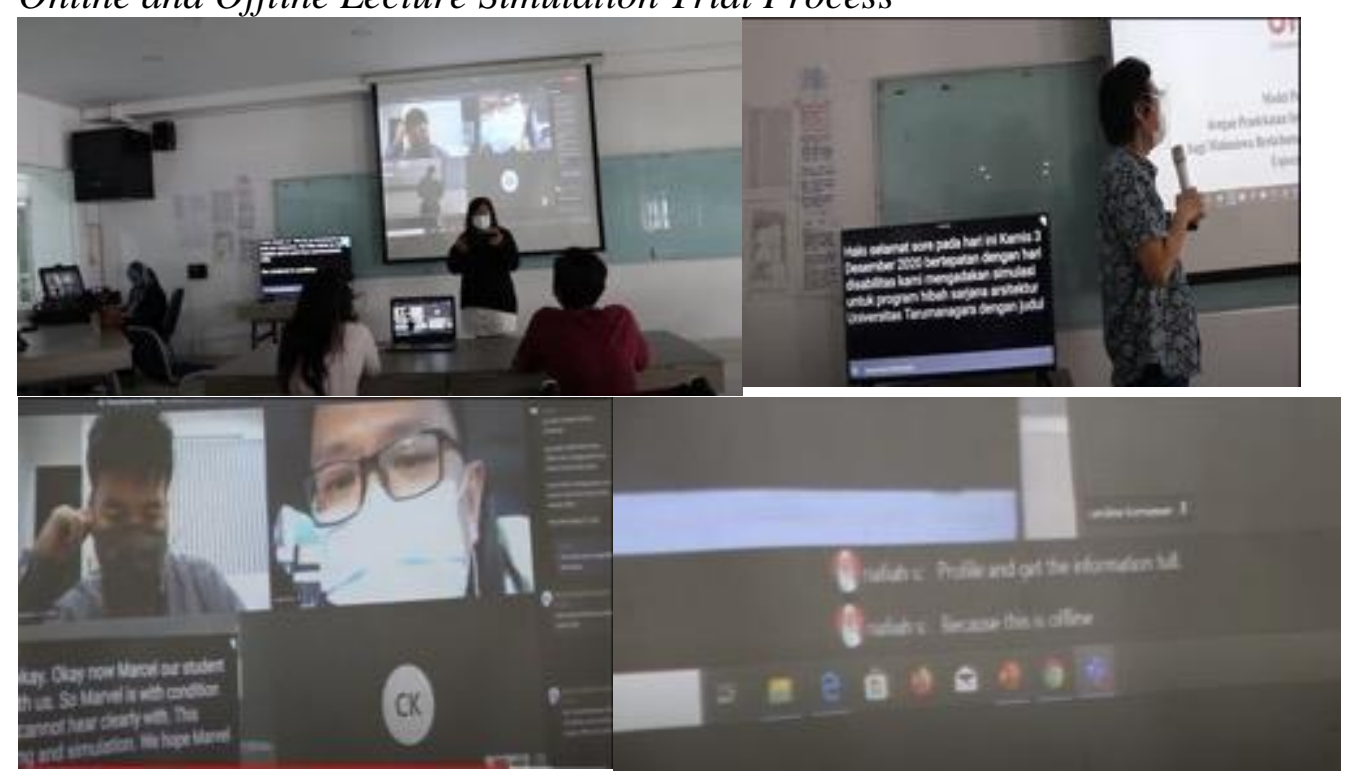

After conducting an offline class lecture simulation trial, an adjustment was made to the distance of the table and space for easy circulation of wheelchair users. The direction of the opening and the door's width should be changed, as shown in Figure 7. 


\section{Figure 7}

The Final Result of The Ideal Layout of The Classroom is The Simulation Result of The Wheelchair Adjustment Trial

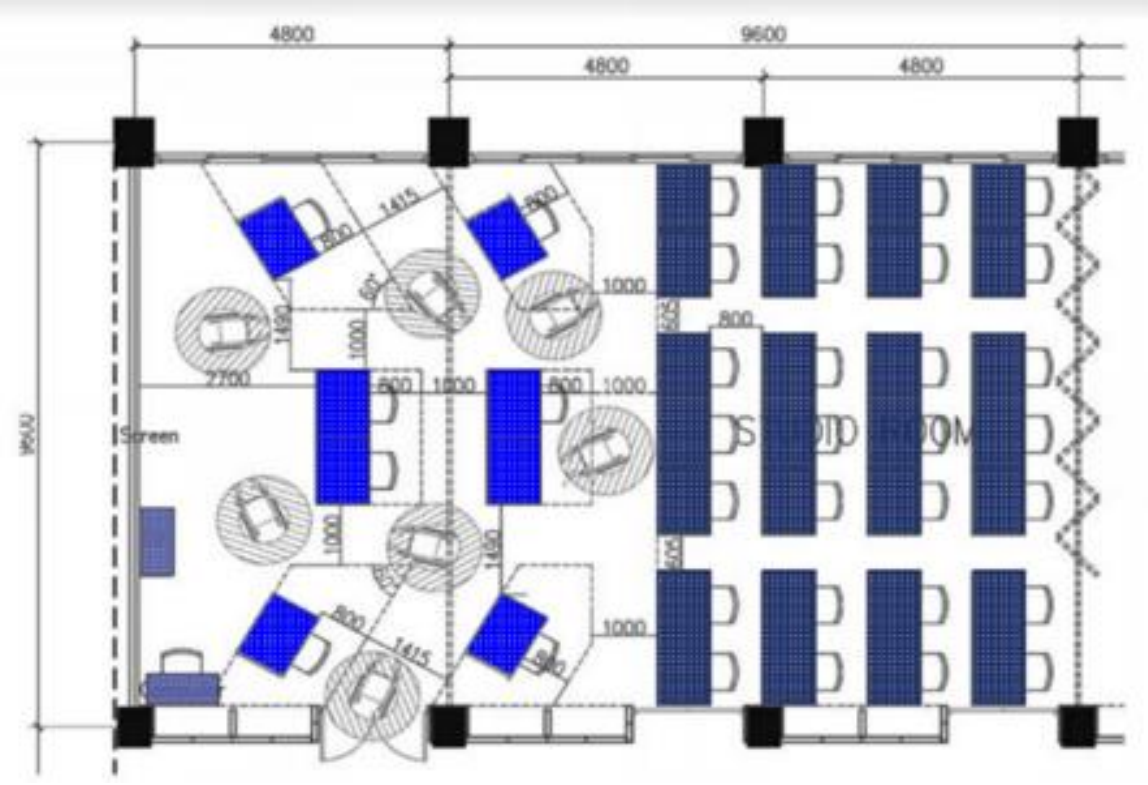

The classroom capacity was reduced to 36 students with the possibility of accommodating 8 students in wheelchairs who have an ideal position to consider visibility, lighting, and reverberation time according to the above analysis (Figure 8).

\section{Figure 8}

The Final Result is An Ideal Classroom Layout With A Capacity Of 36 Students

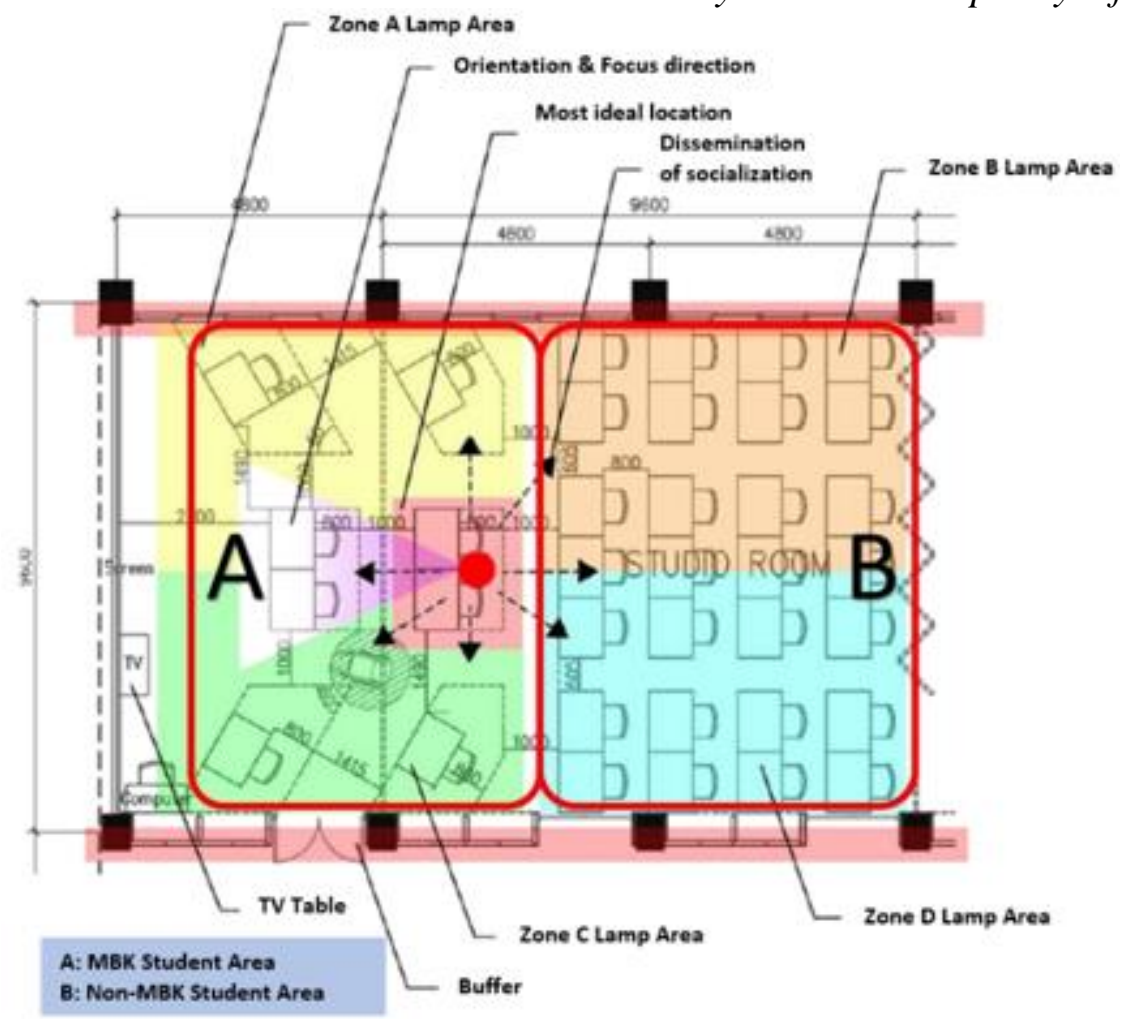




\section{CONCLUSION}

With the assistance of various tools and technologies currently available, as well as the support of knowledge about the character and conditions of people with various disabilities, it can be calculated with sufficient accuracy, methods, placement of tools, and positioning of persons with disabilities in a classroom so that they can attend lectures effectively.

In addition to solutions in terms of classroom arrangement and assistive technology, it is necessary to consider the social aspects of life in the classroom and on campus. This is related to persons with disabilities with other students and lecturers and other personalities. The position of persons with disabilities in the classroom does not need to be "privileged" but creates a feeling of being "separated" alone in the corner of the classroom, but instead is arranged to mingle with other ordinary students. It is necessary to create an atmosphere that in taking education, they are the same.

The development of the resulting innovative learning model is expected to be implemented and can help the learning process for students with special needs. The resulting Innovative Learning Model has also been equipped with media that will be used with applications that support classrooms for MBK with a novelty concept so that MBK can attend lectures comfortably, and the Teaching Staff can deliver lecture materials properly to MBK.

\section{Acknowledgement}

Thanks to the Ministry of Education and Culture, Directorate General of Higher Education (Kementerian Pendidikan dan Kebudayaan, Direktorat Jenderal Pendidikan Tinggi), for funding this research; Resource persons: Yayasan Sayap Ibu which is engaged in social affairs and has several school students with special needs; Christie Damayanti activist in the field of disabilities; Marvel Buhamir, a deaf person and an alumnus of the Architecture Study Program, Department of Architecture and Planning, Faculty of Engineering, Universitas Tarumanagara as a respondent who has provided input and testing of the final results of this research.

\section{REFERENCES}

Bullmer, K. (1975). The art of empathy: A manual for improving accuracy of interpersonal perception. Human Sciences Press.

Desiningrum, D. R. (2016). Psikologi anak berkebutuhan khusus. Psikosain. https://core.ac.uk/download/pdf/76939829.pdf

Diknas, P. N. (2009). Pendidikan inklusif bagi peserta didik yang memiliki kelainan dan memiliki potensi kecerdasan dan/atau bakat istimewa. Menteri Pendidikan Nasional Republik Indonesia. https://jdih.kemdikbud.go.id/arsip/Permendikbud_Tahun2009_Nomor070.pdf

Dikti, P. N. (2017). Pendidikan khusus dan pendidikan layanan khusus di perguruan tinggi. Menteri Riset, Teknologi dan Pendidikan Tinggi Republik Indonesia. https://jdih.ristekbrin.go.id/view-file/?id=bb03b32b-10c5-47c2-b081-8a664be15057

Hallahan, D. P., Kauffman, J. M., \& Pullen, P. C. (2018). Exceptional learners: An introduction to special education (14th ed.). Pearson.

Ishartiwi. (2010). Implementasi pendidikan inklusi bagi anak berkebutuhan khusus dalam sistem persekolahan nasional. Jurnal Pendidikan Khusus, 6(2), 1-9. 
Junaidi, A. (2020). Panduan bantuan dana inovasi pembelajaran dan teknologi bantu (teknologi asistif) untuk mahasiswa berkebutuhan khusus di perguruan tinggi tahun 2020. Direktorat Pembelajaran dan Kemahasiswaan, Direktorat Jenderal Pendidikan Tinggi, Kementerian Pendidikan dan Kebudayaan. Retrieved from http://dikti.kemdikbud.go.id/wpcontent/uploads/2020/08/Panduan-Bantuan-Dana-Inovasi-Pembelajaran-dan-TeknologiBantu-untuk-Mahasiswa-Berkebutuhan-Khusus-di-PT.pdf

Pallasmaa, J., Mallgrave, H. F., Robinson, S., \& Gallese, V. (2015). Architecture and Empathy. (P. Tidwell, Ed.). Tapio Wirkkala Rut Bryk Foundation.

Patria, A., Putra, D., \& Lukito, Y. N. (2018). Architect and empathy: The importance of human experience in architectural design. International Journal of Built Environment and Scientific Research, 2(1), 47-54. Retrieved from https://jurnal.umj.ac.id/index.php/IJBESR/article/view/2825/2383

Praktiningrum, N. (2010). Fenomena penyelenggaraan pendidikan inklusi bagi anak berkebutuhan khusus. Jurnal Pendidikan Khusus, 7(2), 32-39. doi:https://doi.org/10.21831/jpk.v7i2.774

Smith, J. D. (2006). Inklusi, sekolah ramah untuk semua (Inclusion, school for all student). (M. B. Mohammad Sugiarmin, Ed., \& N. E. Denis, Trans.). Nuansa.

Undang-Undang Republik Indonesia Nomor 8 Tahun 2016 Tentang Penyandang Disabilitas. Indonesia. https://pug-pupr.pu.go.id/_uploads/PP/UU.\%20No.\%208\%20Th.\%202016.pdf 